\title{
第 $2 \cdot 3$ 相における適応的計画の基礎理論 \\ Theoretical Basis of Adaptive Designs for Clinical Trials in Phase II and III
}

\author{
杉浦賢吉*1 ・上坂浩之 ${ }^{* 2}$ \\ Kenkichi Sugiura $^{* 1}$ and Hiroyuki Uesaka ${ }^{* 2}$ \\ *1 武田薬品工業株式会社 医薬開発本部 日本開発センター 統計解析部 \\ *2 日本イーライリリーリリーリサーチラボラトリーズジャパン \\ ${ }^{* 1}$ Biostatistics, Japan Development Cent., \\ Pharmaceutical Development Div., Takeda Pharmaceutical Co. \\ ${ }^{* 2}$ Eli Lilly Japan, Lilly Research Laboratories Japan. \\ email: Sugiura_Kenkichi@takeda.co.jp, UESAKA_HIROYUKI@lilly.com
}

\begin{abstract}
Adaptive design is one of the most active research areas in clinical statistics for the last decade. This paper will give an introduction to the theory of two stage adaptive designs based on the pioneering articles by Bauer and Kohne (1994) and Proschan and Hunsberger (1995). As an application of Bauer and Kohne method, Bauer and Kiser method for two stage adaptive dose selection procedure in a dose response study is illustrated. Two actual examples of a confirmatory two treatments trial and a dose response study are briefly given.
\end{abstract}

Key words: adaptive design, Fisher's combination test, inverse normal method, conditional, error function, adaptive dose selection procedure.

\section{1. 背 景}

適応的計画 (adaptive design) は, 医学統計の中で現在最も盛んに研究されている分野のひとつ である. 本計画を扱う産官学のシンポジュームも盛んに開催され，実践に向けての動きが活発で ある. 適応的計画には被験者数の再推定, 試験群の逐次選択, 探索と検証の接続, 評価変数の選 択など様々な計画があり，既に海外ではいくつかの適用が報告されている．筆者らは, 2006 年 12 月に開催された計量生物セミナーにおいて，適応的計画における第 2 相ないし第 $2 \sim 3$ 相で用い られる試験計画の基礎となる理論と実践例を紹介した. 以下はその内容を文章化したものである.

適応的計画は, 試験実施途中に試験計画を変更したり, 試験の中止あるいは継続の判断をした りする試験計画の総称である. 特に, 中間解析の結果を使った試験計画の変更が可能なことが, 本計画が注目される理由と思われる. 適応的計画は多岐にわたるが，その源流を辿ると Bauer and Kohne (1994) と Proschan and Hunsberger (1995) の 2 報に行き着くことが多い.これら 2 報を簡 単に要約するなら， ある試験を複数のステージに分割した上で，前者はステージごとに算出した 統計量 (片側 $p$ 值) を Fisher の $p$ 值の統合検定 (Fisher's product criteria 又は Fisher's combination test) (Fisher (1958)) により統合することを提案したものであり, 後者は複数のステージの結果を Jpn J Biomet Vol. 29, Special Issue 1, 2008 
統合した際の第 1 種の過誤確率を条件付き過誤関数 (conditional error function)により制御する 方法を提案したものである. そして，各ステージでの仮説検定に閉検定手順を組み合わせること で, 複数の仮説の多段階検定及び仮説の絞込みなどを, 多重性による第 1 種の過誤確率を制御し ながら実施することが可能となる．これによって，プラセボと複数用量の多群で第 1 ステージを 開始し，第 1 ステージの中間解析の結果に基づき最も効果の高い用量を選択して第 2 ステージを プラセボと選択された少数の用量群に限定し，最終解析においてプラセボに対する選択された用 量の優越性を検証するといつた適応的 2 段階計画 (adaptive two-stage design) を立案することが 可能となる (Bauer and Kieser (1999), Hommel (2001), Bretz et al. (2005)). 検定は第 1 ステー ジ後の中間解析と第 2 ステージ後の 2 回実施する.

以降の章において, Bauer and Kohne (1994) と Proschan and Hunsberger (1995) を基とした 適応的 2 段階計画の基礎理論を解説する. まず第 2 章において適応的 2 段階計画を概説する. 続 いて第 3 章で代表的な各ステージの結果の統合方法として Fisher の $p$ 值の統合検定と逆正規変 換法 (inverse normal method) (丹後 (2003)) を紹介し, 第 4 章ではそれらの統合方法における第 1 種の過誤確率の制御方法を記す. 第 5 章では条件付き過誤関数による第 1 種の過誤確率の制御方 法の一般化と第 2 ステージの条件付き検出力を解説する. 第 $3 \sim 5$ 章までは 2 群比較のみを考え る単純な試験計画を基に解説する. 第 6 章にて, 複数用量あった場合への拡張として, 第 $3 \sim 5$ 章 で解説した方法と閉検定手順の組合せによる, 用量の絞り込みとプラセボに対する優越性の検証 を目的とした適応的 2 段階計画の検定方法を示す. そして第 7 章にて適応的計画の実施例を簡単 に取り上げる. なお，本報告は適応的計画の設計や解析の基礎となる統計的推測理論の解説を目 的としているので, 適応的計画の適用に当たつての問題や対策には言及しない. いくつかの問題 の指摘は本記録集の森田氏の論文ならびに種々の雑誌に掲載されている論文を参照されたい.

\section{2. 適応的 2 段階計画}

本章では, プラセボ $(\mathrm{P})$ に対するある試験薬 $(\mathrm{T})$ の優越性の検証に関する 2 群比較を例として, 通常の試験デザイン及び群逐次デザインと対比して, 基本的な適応的計画である適応的 2 段階計 画 (adaptive two-stage design)について簡単に説明する. T と P の比較を目的とした並行群試験 において, それぞれの被験者数は等しく $n$ とする. 簡単のために, プラセボ群および試験薬群と も観測值は分散が 1 の正規分布に従うとし, 母平均は未知でそれぞれ $\mu_{p}, \mu_{T}$ とする. T の P に 関する帰無仮説は $H_{0}: \mu_{p}=\mu_{T}$, 対立仮説は $H_{1}: \mu_{p}<\mu_{T}$ である.

通常の試験では, 検定統計量として平均值の差を標準偏差で除した標準正規変数を用いて検定 する. 有意水準を $\alpha$ とすると, $p$ 值が $\alpha$ 以下のとき, $\mathrm{T}$ は $\mathrm{P}$ に優ると結論する. 中間解析を 1 回 行う 2 段階の群逐次計画では, 第 1 回目の検定の有意水準を $\alpha_{1}$, 第 2 回目の検定 (最終の検定)の 形式的な有意水準を $\alpha_{2}$ とすると, 第 1 回の検定は各群 $n_{1}$ 例, 合計 $2 n_{1}$ 例で正規偏差統計量を用 いて検定を行い, $p$ 值が $\alpha_{1}$ 以下であれば $\mathrm{T} か ゙ ~ \mathrm{P}$ に優れると結論して試験を中止し(計画によって は無効中止の判定もなされる), そうでなければ第 2 段階へ進み, 各群で第 2 ステージの $n_{2}$ 例が 組み入れられ試験を終了した段階で, 全 $2 n$ 例を用いて, 通常の正規偏差統計量を求め $p$ 值が $\alpha_{2}$ 以下のとき $\mathrm{T}$ は $\mathrm{P}$ に優ると結論する，検定の繰り返しによる多重性を調整するために， $\alpha_{1}$ およ 
び $\alpha_{2}$ は全体の有意水準 $\alpha$ より 小さく， 2 段階検定で犯す第 1 種の過誤確率が $\alpha$ となるように設 定される.ここで重要なことは, 第 1 ステージ及び第 2 ステージの試験の実施ならびに解析の方 法は全て予め決まっているということである.

適応的 2 段階計画は, 群逐次計画と同様に試験を 2 つのステージに分割し, 第 1 ステージの データによる中間解析を行う。しかし，群逐次計画と異なり，これ以後の判断の仕方および第 2 段階の計画及び解析方法は, 第 1 ステージの結果に基づいて変更することを可能とする方法であ る. もちろん, 試験の全体的な妥当性を保つためには, 変更の範囲と変更の手順について試験の 開始前に定めておかなければならない．第 1 ステージの検定で $p$ 值が予め設定した $\alpha_{1}$ 以下であれ ば Tが $\mathrm{P}$ に優ると結論して試験を中止する. また $p$ 值があらかじめ定めた值 $\alpha_{0}$ 以上であれば, $\mathrm{T}$ は $\mathrm{P}$ に優つてはいないと結論し, 試験を中止する. $p$ 值が $\alpha_{1}$ より大きく $\alpha_{0}$ より小さければ, 第 2 ステージに進む. このとき, 第 1 ステージの結果に基づいて第 2 ステージの被験者数の変更 を検討し，必要であれば変更を許容する方法である．このような変更を可能とするためには，第 一に変更が第 1 種の過誤確率の増大をもたらさないことが必要である. そのためにまず，第 2 ス テージ単独での検定統計量を, 第 1 ステージの検定統計量と独立となるように第 2 ステージの被 験者の夕で求め, この検定統計量に基づく $p$ 值を求める. 第 2 ステージの検定は, 第 1 ステージ の $p$ 值と第 2 ステージの $p$ 值を用いて実施する. 以上の手順の概略を図 1 に示した.

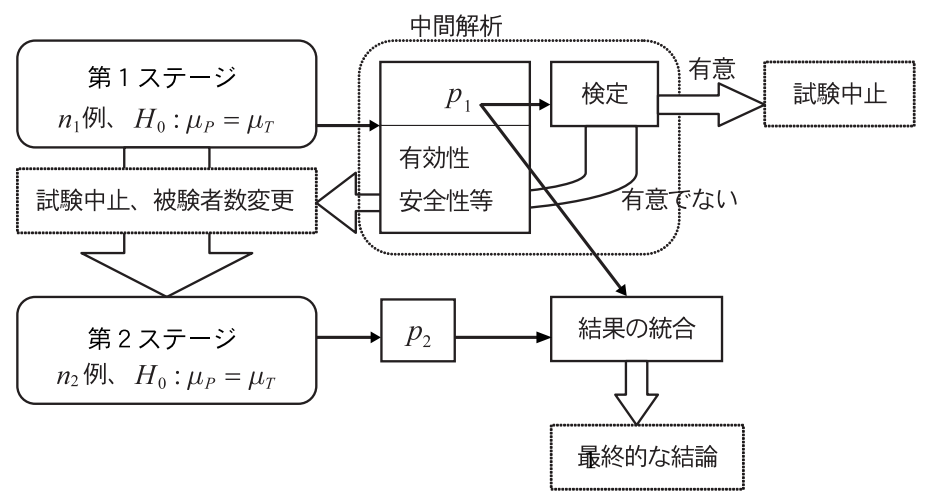

図 1. 適応的 2 段階計画の概略 (各ステージの被験者は重複しない)

適応的 2 段階計画に伴う確率論的な基礎は，このようにして第 1 ステージの結果に基づいて第 2 ステージの計画を決定し，なおかつ，最終の検定が第 1 種の過誤の増大をもたらさないように するための理論と, 第 2 ステージでの計画の変更または決定が, 帰無仮説が誤りであるときに, 試験の検出力を向上することが出来るようにする理論に支えられている. 本稿は，主として第 1 種の過誤の制御の方法について述べる. 中間結果に依存した計画の変更が試験関係者に与える心 理的な作用による試験実施への影響がもたらす偏り, 実施運営の複雑化などの実施上の問題につ いては, 確率論的妥当性と区別して論じることが必要であり, 本稿では扱わない.

なお，優越性の検定では仮説が片側仮説であることから，今後は全て片側確率を用いる．また， 以下の記法を用いる. 標準正規分布の密度関数を $\phi(z)$, 累積分布関数を $\Phi(z)$, 累積分布関数の 逆関数を $\Phi^{-1}(p)$, 及び標準正規分布の $Q$ 分位点を $z_{Q}$, 即ち $z_{Q}=\Phi^{-1}(Q)$, と表す. さらに平 Jpn J Biomet Vol. 29, Special Issue 1, 2008 
均 $\mu$, 分散 $\sigma^{2}$ の正規分布を $N\left(\mu, \sigma^{2}\right)$ と書く. また, 自由度 $K$ のカイ二乗分布に従う確率变数を $\chi^{2}(K)$, その累積確率分布関数の $Q$ 分位点を $\chi_{Q}^{2}(K)$ と表す.

\section{3. 各ステージの結果の統合方法}

各ステージの結果の統合方法の主なものとして, Fisher の $p$ 值の統合検定と逆正規変換法があ る. 本章ではこれらの統合方法について解説する. なお, 本章で紹介する検定結果の統合方法は, 適応的計画に固有の理論ではなく, 独立な試験の結果の統合に関するものである.

本章から第 5 章までは, プラセボ $(\mathrm{P})$ に対するある試験薬 $(\mathrm{T})$ の優越性に関する 2 群比較を想定 する (図 1). 帰無仮説は $H_{0}: \mu_{p}=\mu_{T}$, 対立仮説は $H_{1}: \mu_{p}<\mu_{T}$ である.

\subsection{Fisher の $p$ 值の統合検定}

\subsection{1 $p$ 值の統合方法}

Fisher の $p$ 值の統合検定について述べる. 確率変数 $p$ が $[0,1]$ の一様分布に従う場合, $-2 \ln (p)$ は自由度 2 のカイ二乗分布に従う. また, 被験者が重複しない独立な集団から計算した各 $p$ 值は 統計的に独立であり, 独立な $K$ 個の自由度 2 のカイ二乗変数の和は自由度 $2 K$ のカイ二乗分布に 従う.したがつて, 2 つのステージの $p$ 值 $\left(p_{1}, p_{2}\right)$ の統合において帰無仮説下で以下の関係が成り 立つ.

$$
\left(-2 \ln \left(p_{1}\right)\right)+\left(-2 \ln \left(p_{2}\right)\right)=-2 \ln \left(p_{1} p_{2}\right) \sim \chi^{2}(4) .
$$

第 2 章において, 第 2 ステージの検定の $p$ 值 $\left(p_{2}\right)$ はそのステージで新たに組み入れられた被験者 $\left(2 n_{2}\right.$ 例 $)$ だけを用いて計算すると述べたが，それは $p$ 值の統合において各 $p$ 值の独立性が前提と なっているためである.

いま，第 1 ステージでの棄却を考えず，第 2 ステージまで進んだ後に 2 つのステージの結果を 統合して検定するとすれば, 2 つのステージの結果について $-2 \ln \left(p_{1} p_{2}\right) \geq \chi_{1-\alpha}^{2}(4)$ であれば有意 水準 $\alpha$ で有意となる. この式を変形すると, $p_{1} p_{2} \leq c_{\alpha}=\exp \left(-\chi_{1-\alpha}^{2}(4) / 2\right)$ のとき帰無仮説を衰 却することになる.

\section{$3.1 .2 p$ 值の統合による 2 段階検定の概略}

一方, 適応的 2 段階計画では, 第 1 ステージで $p_{1}<\alpha_{1}$ のとき帰無仮説を棄却し, $p_{1}>\alpha_{1}$ の ときに限り, 必要に応じて被験者数を再推定した上で第 2 ステージに進み, 第 2 回目の検定を 実施する．このとき，第 2 回の検定として，上記の $p$ 值の統合検定を用いると， 2 回目の検定は $p_{1} p_{2} \leq c_{\alpha}=\exp \left(-\chi_{1-\alpha}^{2}(4) / 2\right)$ のとき, 即ち $p_{2} \leq c_{\alpha} / p_{1}$ のときに帰無仮説を棄却することになる. したがって，第 2 ステージのデータから計算した $p_{2}$ の棄却限界值は, 第 1 ステージの結果である $p_{1}$ に依存することがわかる．言い換えれば，第 2 ステージの検定は第 1 ステージの結果である $p_{1}$ を条件とした条件付き検定である.ここに述べた 2 段階検定では繰り返し検定に伴う第 1 種の過 誤確率の増大を考慮していない。途中中止を許容したうえで, 第 1 ステージの結果に条件付けら れた繰り返し検定の衰却限界を定める検定方式における第 1 種の過誤確率の制御方法は第 4 章で 述べる. 


\subsubsection{Fisher の $p$ 值の統合検定による検出力の損失}

Bauer and Kohne (1994) は, Fisher の $p$ 值の統合検定による検出力の損失に関するいくつかの場 合に関する理論計算の結果を示している. 分散既知 $(\sigma)$ の正規分布について $H_{0}: \mu=0, H_{1}: \mu>0$ の検定を考える. 全例 $(n$ 例) を用いた場合の一様最強力検定の統計量は $z=\bar{x} \sqrt{n} / \sigma$ であり, $p$ 值 は $1-\Phi(z)$ である. ここに $\bar{x}$ は $n$ 例の観測值の平均值である. このデー夕を $n_{1}$ 例と $n_{2}$ 例に分 割し $\left(n=n_{1}+n_{2}\right)$, 各集団の一様最強力検定の統計量を $Z_{1}, Z_{2}$, それらの実現值を $z_{1}, z_{2}$ とす ると, 各集団の $p$ 值は $p_{1}=1-\Phi\left(z_{1}\right), p_{2}=1-\Phi\left(z_{2}\right)$ となる. これらの $p$ 值を Fisher の $p$ 值の統 合公式により統合する. 全例を対象とした一様最強力検定の検出力が $80 \%$ の場合の, Fisher の $p$ 值の統合検定の検出力は, $r=n_{1} /\left(n_{1}+n_{2}\right)=0.5$ では $77.8 \%, r=0.2$ では $76.4 \%$ であり, 検出 力の低下は小さいことが示された. したがって，部分集団に分割した上で $p$ 值を統合する検定方 式は実用に耐えると考えられた。

\section{2 逆正規変換法}

逆正規変換法 (inverse normal method) は, 確率変数 $P$ が $[0,1]$ の一様分布に従う場合, $P$ に対 応する標準正規分布の分位点の值は $N(0,1)$ に従う確率変数であることを利用した方法である. さ らに, 標準正規分布に従う独立な 2 つの確率変数の和は $N(0,2)$ に従い, その和を $\sqrt{2}$ で割れば 標準化されることを利用することで, 2 つのステージの $p$ 值 $\left(p_{1}, p_{2}\right)$ を統合できる. つまり, $2 \supset$ のステージの $Z_{1}, Z_{2}$ について帰無仮説下で以下の関係が成り立つ.

$$
\left(Z_{1}+Z_{2}\right) / \sqrt{2} \sim N(0,1), \quad Z_{1}=\Phi^{-1}\left(1-P_{1}\right), \quad Z_{2}=\Phi^{-1}\left(1-P_{2}\right) .
$$

いま，第 1 ステージでの棄却を考えず，第 2 ステージまで進んだ後に 2 つのステージの結果を 統合して検定するとすれば, 2 つのステージの結果について $\left(z_{1}+z_{2}\right) / \sqrt{2} \geq z_{1-\alpha}$ であれば有意水 準 $\alpha$ で有意となる.

一方, 適応的 2 段階計画では, 第 1 ステージで $p_{1}<\alpha_{1}$ のとき帰無仮説を棄却し, $p_{1}>\alpha_{1}$ のと きに限り第 2 ステージに進み，第 2 回目の検定を実施するという 2 段階検定を行う．このとき，第 2 ステージの検定に $Z_{1}$ と $Z_{2}$ を用いた統合検定を適用すると, 第 2 ステージでは $z_{2} \geq \sqrt{2} z_{1-\alpha}-z_{1}$ のときに帰無仮説を棄却することとなる. したがって，第 2 ステージのデータから計算した $z_{2}$ の 棄却限界值は，第 1 ステージの結果である $z_{1}$ に依存することがわかる. Fisher の $p$ 值の統合検 定と同様, 第 2 ステージの検定は第 1 ステージの結果を条件とした条件付き検定となっている. このことを利用して第 1 種の過誤確率の制御を行う (第 4 章).

上記の方法は $Z_{1}$ と $Z_{2}$ の重みが等しい場合であるが, 異なる重み $w_{1}$ と $w_{2}$ を用いることも 可能である (重み付き逆正規変換法)。その場合, 重みの二乗和が 1 , つまり分散の和が 1 にな るように重みを設定すればよい. 即ち $\sum w_{i}^{2}=1$ として, $w_{1} z_{1}+w_{2} z_{2} \geq z_{1-\alpha}$ のとき有意水準 $\alpha$ で有意と判定する. 重みには事前に定めた各ステージの例数 $n_{1}, n_{2}$ がよく用いられる. そ の場合, $w_{1}=\sqrt{n_{1} /\left(n_{1}+n_{2}\right)}, w_{2}=\sqrt{n_{2} /\left(n_{1}+n_{2}\right)}$ として, $w_{1} z_{1}+w_{2} z_{2} \geq z_{1-\alpha}$, つまり $z_{2} \geq$ $\left(z_{1-\alpha} \sqrt{n_{1}+n_{2}}-z_{1} \sqrt{n_{1}}\right) / \sqrt{n_{2}}$ であれば有意水準 $\alpha$ で有意となる. 


\section{4. 第 1 種の過誤確率の制御}

前章の 2 段階検定における統合検定の解説は，独立な 2 つの標本の各々における検定統計量か ら単一の統合検定統計量を生成する方法のみを扱つており，第 1 ステージの検定との多重性を考 慮していないため, 試験全体の第 1 種の過誤確率が $\alpha$ 以下に制御されない. そこで本章では 2 段 階試験における試験全体の第 1 種の過誤確率の計算と制御について手法ごとに解説する.

前章において第 2 ステージの検定は第 1 ステージの結果 $\left(p_{1}\right.$ または $\left.z_{1}\right)$ を条件とした条件付き 検定となることを示したが, 条件について全ての場合 $\left(p_{1}\right.$ なら $0 \sim 1, z_{1}$ なら $\left.-\infty \sim \infty\right)$ を考慮 すれば試験全体として有意となる確率がわかり，これを帰無仮説下で考えれば試験全体の第 1 種 の過誤確率が計算可能となる. ここで第 1 ステージの中間解析の結果, $p_{1}<\alpha_{1}$ であれば帰無仮 説を棄却して試験中止 (有効中止), $p_{1}>\alpha_{0}$ であれば帰無仮説を採択して試験中止 (無効中止), $\alpha_{1}<p_{1}<\alpha_{0}$ であれば試験継続(第 2 ステージへ進む)とする.

第 1 ステージでの有効中止である $p_{1}<\alpha_{1}$ では, 有意水準 $\alpha_{1}$ で帰無仮説を棄却して試験を中止 するため, 第 1 回の検定で犯す第 1 種の過誤確率は $\alpha_{1}$ である. 試験が継続される $\alpha_{1}<p_{1}<\alpha_{0}$ の場合には, 条件付き検定の第 1 種の過誤確率に $p_{1}$ の発生確率密度を乗じて当該区間で積分すれ ば第 1 種の過誤確率が計算できる. 無効中止である $p_{1}>\alpha_{0}$ では, 帰無仮説を採択して試験を中 止するため第 1 種の誤りを犯さないので, 第 1 種の過誤確率への寄与はない.

Fisher の $p$ 值の統合検定の場合, 第 2 ステージの検定は $p_{2} \leq c_{\alpha} / p_{1}, c_{\alpha}=\exp \left(-\chi_{1-\alpha}^{2}(4) / 2\right)$ の ときに帰無仮説を棄却することとすれば，帰無仮説のもとでは $P_{1}$ の分布は $[0,1]$ の一様分布であ り, その確率密度関数は 1 であることから, 継続の可能性を考慮した試験全体の第 1 種の過誤確 率は

$$
\alpha_{1}+\int_{\alpha_{1}}^{\alpha_{0}}\left(c_{\alpha} / p_{1}\right) 1 d p_{2} d p_{1}+0=\alpha_{1}+c_{\alpha}\left(\ln \alpha_{0}-\ln \alpha_{1}\right)
$$

である. したがって, $\alpha_{1}+c_{\alpha}\left(\ln \alpha_{0}-\ln \alpha_{1}\right)=\alpha$ を満たすようにパラメータ $\alpha_{1}$ と $\alpha_{0}$ を定めればよ い. これは，無効中止を導入することにより， $p_{1} \geq \alpha_{0}$ 又は $p_{1} p_{2} \leq c_{\alpha}$ となる事象の確率を，第 1 ス テージで帰無仮説を棄却する確率に使用することを意味する. ただし， $0<c_{\alpha} \leq \alpha_{1}<\alpha<\alpha_{0} \leq 1$ の条件が付く. $c_{\alpha} \leq \alpha_{1}$ の部分は，有効中止の際に $p_{1} p_{2} \leq c_{\alpha}$ が任意の $p_{2}$ に対して成立するため の条件である.

これらの条件を満たす $\alpha_{1}, \alpha_{0}$ は任意に設定可能である. 例えば $\alpha$ と $\alpha_{0}$ を与えた場合の $\alpha_{1}$ は, $\alpha_{1}+c_{\alpha}\left(\ln \alpha_{0}-\ln \alpha_{1}\right)=\alpha$ を $\alpha_{1}$ に関して解いて得られる. あるいは，もつと一般的には， $\alpha_{1}, \alpha_{0}$ を与えて, $c(\alpha)=\left(\alpha-\alpha_{1}\right) /\left(\ln \alpha_{0}-\ln \alpha_{1}\right)$ として第 2 ステージの検定では $p_{2}<c(\alpha) / p_{1}$ のときに 仮説を棄却するとしてもよい.

逆正規変換法の場合, 第 2 ステージの検定の形式的な有意水準を $\alpha_{2}$ として, $z_{2} \geq \sqrt{2} z_{1-\alpha_{2}}-z_{1}$ のときに帰無仮説を棄却する． $\alpha_{2}$ は以下のようにして定まる. 第 1 ステージの検定統計量 $Z_{1}$ に ついて, $z_{1-\alpha_{1}} \leq z_{1}$ のとき有効中止, $z_{1-\alpha_{0}} \leq z_{1}<z_{1-\alpha_{1}}$ のとき試験継続, $z_{1}<z_{1-\alpha_{0}}$ のとき無 効中止とすると, 試験全体の第 1 種の過誤確率は $\alpha_{1}+\int_{z_{1-\alpha_{0}}}^{z_{1-\alpha_{1}}}\left(1-\Phi\left(\sqrt{2} z_{1-\alpha_{2}}-z_{1}\right)\right) \phi\left(z_{1}\right) d z_{1}+0$ で与えられるので, この值が $\alpha$ 以下になるように $\alpha_{0}, \alpha_{1}, \alpha_{2}$ を設定すれば，試験全体の第 1 種の 過誤確率が $\alpha$ 以下に制御できる. 同様に, 重み付き逆正規変換法における試験全体の第 1 種の過 
誤確率は

$$
\alpha_{1}+\int_{z_{1-\alpha_{0}}}^{z_{1-\alpha_{1}}}\left\{1-\Phi\left[\left(z_{1-\alpha_{2}} \sqrt{n_{1}+n_{2}}-z_{1} \sqrt{n_{1}}\right) / \sqrt{n_{2}}\right]\right\} \phi\left(z_{1}\right) d z_{1}+0
$$

となる.

本章の第 1 種の過誤確率の制御は, 帰無仮説のもとで $p$ 值が一様分布に従うことを前提として いるが，もう少し緩い条件のもとで制御可能であることが, Brannath, Posch and Bauer (2002) で示されている.これについては第 6 章で述べる.

\section{5. 条件付き過誤関数}

前章において, 統合方法ごとに, 第 2 ステージにおける条件付き検定の条件 $p_{1}$ または $z_{1}$ につ いてその全変域にわたつて積分することで試験全体の第 1 種の過誤確率が与えられることを述べ た.この条件付き検定の考え方を一般化して条件付き過誤関数 (conditional error function) を定義 する． 条件付き過誤関数は，第 1 ステージの結果 $p_{1}$ または $z_{1}$ が与えられた場合に，第 2 ステー ジで帰無仮説を棄却する確率として定義する.この棄却確率は, 帰無仮説下では, $p_{1}$ が与えられ た条件の下での, 第 2 ステージの検定統計量 $P_{2}$ における棄却限界值又は第 2 ステージの第 1 種 の過誤確率となる.さらに，条件である第 1 ステージの結果 $p_{1}$ または $z_{1}$ について，条件付事象 の確率密度を乗じて全変域にわたつて積分すれば試験全体で犯す第 1 種の過誤確率となる. 一方, この条件付き過誤関数は, 対立仮説下では第 2 ステージの条件付き検出力 (conditional power) と なる.

\section{1 条件付き過誤関数による第 1 種の過誤確率の制御}

条件付き過誤関数を使った各統合検定の第 1 種の過誤確率の制御を以下に記す.なお帰無仮説 下の条件付き過誤関数は $A\left(p_{1}\right)$ 又は $A\left(z_{1}\right)$ と表記する. 本節では, 帰無仮説のもとで, 検定統計 量は標準正規分布に従うか, 検定の $p$ 值は $[0,1]$ 上の一様分布に従うことを前提とする. 後に, 多 重仮説の検定において, 多重性の調整を施したときの $p$ 值は常に一様分布に従うわけではないこ とに注意しょう.

\subsubsection{Fisher の $p$ 值の統合における条件付き過誤関数}

Fisher の $p$ 值の統合検定において, 第 2 ステージの条件付き検定の棄却限界值は $c_{\alpha} / p_{1}$ である ため, 試験継続した場合, 帰無仮説下で, 第 1 ステージの結果 $p_{1}$ が与えられた場合に第 2 ステー ジで帰無仮説が棄却される確率は $c_{\alpha} / p_{1}$ である. また, 積分を行う際の便宜的な表現として第 1 ステージで有効中止した場合を $A\left(p_{1}\right)=1$, 無効中止した場合を $A\left(p_{1}\right)=0$ とする. Fisher の $p$ 值 の統合検定の条件付き過誤関数は

$$
A\left(p_{1}\right)=\left\{\begin{array}{lll}
0 & \text { if } & p_{1}>\alpha_{0} \\
c_{\alpha} / p_{1} & \text { if } & \alpha_{1} \leq p_{1} \leq \alpha_{0} \\
1 & \text { if } & p_{1}<\alpha_{1}
\end{array}\right.
$$

となる. 試験全体の第 1 種の過誤確率の計算は， $A\left(p_{1}\right)$ を $p_{1}$ の全区間で積分すれば良い.この式 から分かるように, 条件付過誤関数は各ステージの例数に依存しない. 


\subsection{2 逆正規変換における条件付き過誤関数}

逆正規変換法においては, 第 2 ステージの条件付き検定の棄却限界值が $\sqrt{2} z_{1-\alpha_{2}}-z_{1}$ である ため, 帰無仮説下で, 第 1 ステージの結果 $z_{1}$ が与えられた場合に第 2 ステージで帰無仮説が棄却 される確率は $1-\Phi\left(\sqrt{2} z_{1-\alpha_{2}}-z_{1}\right)$ である. 積分を行う際の便宜的な表現として, 第 1 ステージ で有効中止した場合を $A\left(z_{1}\right)=1$, 無効中止した場合を $A\left(z_{1}\right)=0$ とする. 逆正規変換法の条件付 き過誤関数は

$$
A\left(z_{1}\right)=\left\{\begin{array}{lll}
0 & \text { if } & z_{1}<z_{1-\alpha_{0}} \\
1-\Phi\left(\sqrt{2} z_{1-\alpha_{2}}-z_{1}\right) & \text { if } & z_{1-\alpha_{0}} \leq z_{1} \leq z_{1-\alpha_{1}} \\
1 & \text { if } \quad z_{1}>z_{1-\alpha_{1}}
\end{array}\right.
$$

となる．試験全体の第 1 種の過誤確率は, $A\left(z_{1}\right)$ を $z_{1}$ の全区間で積分して得られる．標準正規分 布である $z_{1}$ の確率密度関数を $\phi\left(z_{1}\right)$ とすると, 試験全体の第 1 種の過誤確率は

$$
\int_{-\infty}^{\infty} A\left(z_{1}\right) \phi\left(z_{1}\right) d z_{1}=\alpha_{1}+\int_{z_{1-\alpha_{0}}}^{z_{1-\alpha_{1}}}\left(1-\Phi\left(\sqrt{2} z_{1-\alpha_{2}}-z_{1}\right)\right) \phi\left(z_{1}\right) d z_{1}+0
$$

と計算され，この值が $\alpha$ 以下になるように各変数を設定すれば, 試験全体の第 1 種の過誤確率が $\alpha$ 以下に制御される.

同様に，重み付き逆正規变換法の条件付き過誤関数は

$$
A\left(z_{1}\right)=\left\{\begin{array}{lll}
0 & \text { if } & z_{1}<z_{1-\alpha_{0}} \\
1-\Phi\left[\left(z_{1-\alpha_{2}} \sqrt{n_{1}+n_{2}}-z_{1} \sqrt{n_{1}}\right) / \sqrt{n_{2}}\right] & \text { if } & z_{1-\alpha_{0}} \leq z_{1} \leq z_{1-\alpha_{1}} \\
1 & \text { if } & z_{1}>z_{1-\alpha_{1}}
\end{array}\right.
$$

となる.

重み付きでない条件付き過誤関数は各ステージの例数に依存しないが, 各ステージの例数で重 み付けした条件付過誤関数は, 各ステージの例数に依存するため, 重みとしての例数は, 試験開 始前に設定した第 2 ステージの例数を用いなければならない。もしも再設計後の第 2 ステージ の例数 $\left(n_{2}^{*}\right)$ を用いると, 第 1 種の過誤確率は $\alpha$ 以下に制御されない. Proschan and Hunsberger (1995) に, 重みに $n_{2}^{*}$ を用いた際の第 1 種の過誤確率の理論的な最大值が記されている. それに よると, $\alpha=0.05$ (片側) とした場合の第 1 種の過誤確率は 0.1146 であり, 試験全体の第 1 種の過 誤確率は $\alpha$ 以下に制御されないことがわかる.

\subsection{3 条件付き過誤関数の拡張}

条件付き過誤関数を用いて, 試験全体の第 1 種の過誤確率を一般的に,

$$
\int_{0}^{1} A\left(p_{1}\right) d p_{1}=\alpha, \quad \text { または }, \quad \int_{-\infty}^{\infty} A\left(z_{1}\right) \phi\left(z_{1}\right) d z_{1}=\alpha
$$

と記述することができる.これらの式を第 1 ステージの中止確率を含めて表現すると，

$$
\alpha_{1}+\int_{\alpha_{1}}^{\alpha_{0}} A\left(p_{1}\right) d p_{1}=\alpha, \quad \text { または }, \quad \alpha_{1}+\int_{z_{1-\alpha_{0}}}^{z_{1-\alpha_{1}}} A\left(z_{1}\right) \phi\left(z_{1}\right) d z_{1}=\alpha
$$


となる.これらの式を満たす $A\left(p_{1}\right), A\left(z_{1}\right)$ は任意に与えることができる. 言い換えれば, 結果の 統合方法は, Fisher の $p$ 值の統合検定と逆正規変換法だけでなく, 任意に設定することが可能で ある.

$A\left(p_{1}\right), A\left(z_{1}\right)$ は試験の経過時点により意味が異なる. 試験開始前であれば未知の $p_{1}$ または $z_{1}$ を変数とした関数であり, 中間解析後であれば既知の定数 $p_{1}, z_{1}$ から計算される第 2 ステージの 棄却限界值である. なお, 条件付き過誤関数による実際の第 1 種の過誤確率の計算は数值積分に より実行可能である.

\subsubsection{Circular conditional error function}

Proschan and Hunsberger (1995) は, 重み付き逆正規変換法の条件付き過誤関数として, 彼ら が circular conditional error function と名づけた関数を提案している.この過誤関数は, $n_{2}$ を変 数 (再設計可能) と考えて $\int_{-\infty}^{\infty}\left\{1-\Phi\left[\left(z_{1-\alpha} \sqrt{n_{1}+n_{2}}-z_{1} \sqrt{n_{1}}\right) / \sqrt{n_{2}}\right]\right\} \phi\left(z_{1}\right) d z_{1}$ の最大値を与え る関数として求められた. つまり, 第 2 ステージの例数に関わらず第 1 種の過誤確率を制御でき る関数である. $\alpha$ が最大となる条件は $n_{2} / n_{1}=\left(z_{1-\alpha}^{2}-z_{1}^{2}\right) / z_{1}^{2}$ であり, $\alpha_{0}, \alpha_{1}$ の条件を加味する ことで以下の条件付き過誤関数が得られる.

$$
A_{\text {cir }}\left(z_{1}\right)=\left\{\begin{array}{lll}
0 & \text { if } & z_{1}<z_{1-\alpha_{0}} \\
1-\Phi\left(\sqrt{z_{1-\alpha_{1}}^{2}-z_{1}^{2}}\right) & \text { if } & z_{1-\alpha_{0}} \leq z_{1} \leq z_{1-\alpha_{1}} . \\
1 & \text { if } \quad z_{1}>z_{1-\alpha_{1}}
\end{array}\right.
$$

なお， $A_{\text {cir }}$ の「 $「 \mathrm{cir} 」 は$ circular の略だが，これは円周を表す関数 $\left(x^{2}+y^{2}=a\right)$ に由来する. この 式からも分かるように, $A_{\text {cir }}$ は各ステージの例数に依存しない.

\section{2 条件付き検出力}

第 2 ステージにおける対立仮説下における条件付き過誤関数は条件付き検出力を意味する. プ ラセボ群の母平均を $\mu_{P}$, ある試験薬群の母平均を $\mu_{T}$ とし, 共通の既知の母分散を $\sigma^{2}$ とする. 第 2 ステージのプラセボ群の平均值を $\bar{x}_{2}$, 試験薬群のデータの平均值を $\bar{y}_{2}$ とする. 母平均の差 に対する検定を想定し, $\delta=\left(\mu_{P}-\mu_{T}\right) / \sigma$ とおく. Fisher の $p$ 值の統合検定による条件付き検出 力は以下のようになる。

$$
\begin{aligned}
\operatorname{Pr}\left(p_{1} p_{2}<c_{\alpha} \mid p_{1}, \delta\right)=\operatorname{Pr}\left(p_{2}<c_{\alpha} / p_{1} \mid \delta\right) \\
\quad=\operatorname{Pr}\left(\frac{\left(\bar{x}_{2}-\bar{y}_{2}\right)}{\sqrt{2 \sigma^{2} / n_{2}}}>z_{c_{\alpha}} / p_{1} \mid \delta\right) \\
\quad=\operatorname{Pr}\left(\frac{\left(\bar{x}_{2}-\bar{y}_{2}\right)-\left(\mu_{P}-\mu_{T}\right)}{\sqrt{2 \sigma^{2} / n_{2}}}>z_{c_{\alpha} / p_{1}}-\frac{\mu_{P}-\mu_{T}}{\sqrt{2 \sigma^{2} / n_{2}}} \mid \delta\right) \\
=\operatorname{Pr}\left(\frac{\left(\bar{x}_{2}-\bar{y}_{2}\right)-\left(\mu_{P}-\mu_{T}\right)}{\sqrt{2 \sigma^{2} / n_{2}}}>z_{c_{\alpha} / p_{1}}-\delta \sqrt{n_{2} / 2}\right) \\
=1-\Phi\left(z_{c_{\alpha} / p_{1}}-\delta \sqrt{n_{2} / 2}\right) .
\end{aligned}
$$

逆正規変換法についても同様に,

$$
\operatorname{Pr}\left(\left(Z_{1}+Z_{2}\right) / \sqrt{2}>z_{1-\alpha_{2}} \mid \delta\right)=\operatorname{Pr}\left(Z_{2}>\sqrt{2} z_{1-\alpha_{2}}-z_{1} \mid \delta\right)=1-\Phi\left(\sqrt{2} z_{1-\alpha_{2}}-z_{1}-\delta \sqrt{n_{2} / 2}\right)
$$

Jpn J Biomet Vol. 29, Special Issue 1, 2008 
となる. これを一般化すると, 平均值の差における条件付き検出力は, $1-\Phi\left(z_{A}-\delta \sqrt{n_{2} / 2}\right)$ とな る. $z_{A}$ は $z_{A\left(z_{1}\right)}$ を略したもので, 条件付き過誤関数により計算した第 2 ステージの棄却限界值 である.

このように, 対立仮説の下では統合検定統計量の分布は各ステージの例数に依存する. した がって, 適応的計画における被験者数再設計は, 一般的に, 条件付き検出力が $1-\beta_{2}\left(\beta_{2}\right.$ は第 2 ステージの条件付き検定における検出力）となるような $n_{2}$ を求めることで行われる. 上記の例で は $1-\Phi\left(z_{A}-\delta \sqrt{n_{2} / 2}\right)=1-\beta_{2}$ を $n_{2}$ について解き, $n_{2}=2\left(z_{A}+z_{1-\beta_{2}}\right)^{2} / \delta^{2}$ となる.

\section{6. 複数の群の間の比較}

第 $3 \sim 5$ 章において, 単純な 2 群比較の適応的 2 段階計画における結果の統合方法と第 1 種の 過誤確率の制御方法について述べた. この方法をプラセボと複数用量の比較試験の場合に拡張 する一つの方法は，たとえば，各用量とプラセボの 2 群比較の全体からなる検定の族に関する family-wise error rate (FWER)の制御を目的として閉検定手順を導入し，さらに，中間解析によ る多重性の補正を加えればよい，このようにして，中間解析後にある用量を中止または継続した 場合でも, 試験全体で第 1 種の過誤を制御することができる. 本章に紹介する方法の基礎的な理 論は, Bauer and Kieser によって与えられ，その後 Hommel や, Bretz らによって特別な状況の 場合への適用が議論されている. さらに, 複数の仮説について多重性を考慮して検定するために, $p$ 值の調整が必要となる. 例えば Bonferroni 型の $p$ 值の調整に基づき, 各仮説の $p$ 值を定義する と, 調整 $p$ 值は帰無仮説の下でも一様分布に従わない. この場合でも, 既に導入した条件付過誤 関数を用いて第 1 種の過誤を制御することが出来ることは, Brannath, Posch and Bauer (2003) で示されている. この点については 6.2 節で解説する.

\section{1 閉検定手順}

閉検定手順について簡単に解説する. なお, 本 6.1 節の内容は森川 (2008), 三輪 (2008) におい て詳細に, かつ, わかりやすくまとめられている. まずはそちらをご覧頂きたい.

ある薬剤の 2 つの用量(低用量：L, 高用量：H)について, いずれかの用量のプラセボに対する 優越性の検証を目的とした試験を想定する.

まず，適応的 2 段階計画を考えない一般的な各用量とプラセボの 2 群比較を考える. 用量 L 群, $\mathrm{H}$ 群およびプラセボ群の母平均を, それぞれ $\mu^{L}, \mu^{H}$ および $\mu^{P}$ とする. 基本帰無仮説 (以降では 基本仮説という)は $H_{0}^{L}: \mu^{P}=\mu^{L}, H_{0}^{H}: \mu^{P}=\mu^{H}$ の 2 つである. 閉検定手順より, FWER を名 目有意水準 $\alpha$ 以下に保ちつつ仮説 $H_{0}^{L}$ を棄却するためには, $H_{0}^{L}$ および $H_{0}^{L} \cap H_{0}^{H}\left(H_{0}^{L}\right.$ を含意す る (imply) 全ての積仮説)のそれぞれが有意水準 $\alpha$ で棄却される必要がある. 以下, $H_{0}^{L}$ の検定の $p$ 值を $p^{L}, H_{0}^{H}$ の検定の $p$ 值を $p^{H}, H_{0}^{L} \cap H_{0}^{H}$ の検定の調整 $p$ 值を $p^{L H}$ とする.

多重性を考慮して $H_{0}^{L} \cap H_{0}^{H}$ を検定するために, Bonferroni 不等式による多重性調整法を適用 すると, $p^{L}<\alpha$ 且つ $p^{L H}=2 \min \left(p^{L}, p^{H}\right)<\alpha$ であつた場合に $H_{0}^{L}$ が棄却される. 同様に $p^{H}<\alpha$ 且つ $p^{L H}=2 \min \left(p^{L}, p^{H}\right)<\alpha$ であった場合に $H_{0}^{H}$ が棄却される.

仮説 $H_{0}^{L}$ と $H_{0}^{H}$ の検定にあたり, 検定する順序を導入する方法(仮説の重要性に基づく順序関係 を導入する方法)を用いることも出来る. 例えば試験計画時に各用量の平均值に大小関係 $\mu^{L} \leq \mu^{H}$ 
を仮定できる場合，すなわち低用量が有効であるならば高用量は有効であることを前提とする場 合に, この方法が適用可能となる. なお, この仮定は各仮説の順序を $H_{0}^{H} \succ H_{0}^{L}$ （記号 $A \succ B$ は, $\mathrm{B}$ より $\mathrm{A}$ が重要であるという意味) と定めることと同じであるため, 以後は「 $\left.H_{0}^{H} \succ H_{0}^{L}\right\rfloor$ の表 現で統一する. また, このような順序を定める場合, 重要性の順序に従って, 検定される仮説の 間に階層構造が導入されていることが必要である. 仮説を定める条件間の論理的関係によって, 帰無仮説 $H_{H 01}$ が成り立つならば帰無仮説 $H_{H 02}$ が成り立つとき, $H_{H 01}$ は $H_{H 02}$ を含意すると いうことにしよう．このことは次のように言うこともできる．考えている仮説全体を規定するパ ラメータの組において， $H_{H 01}$ によって定まる制約条件は， $H_{H 02}$ によって定まる制約条件を含 んでいる，換言すれば， $H_{H 02}$ によって定まる制約条件に新たな制約条件を追加することによっ て $H_{H 01}$ が定義される．したがって， $H_{H 02}$ の制約条件の定める命題を $H_{H 01}$ は含んでいる．こ の意味において， $H_{H 01}$ は $H_{H 02}$ を含意するといってよい。ささて ある帰無仮説が棄却されるな らその帰無仮説を含意する全ての帰無仮説が棄却されることが前提となる. 例えば仮説の順序を $H_{0}^{H} \succ H_{0}^{L}$ と定めるとする. 積仮説 $H_{0}^{L H}=H_{0}^{L} \cap H_{0}^{H}$ は, 第 1 順位の基本仮説 $H_{0}^{H}$ が棄却されれ ば棄却できるので, 名目有意水準を $\alpha$ として $H_{0}^{H}$ を $\alpha$ で棄却できれば良いことになる. 続いて $H_{0}^{L}$ の検定では, 閉検定手順の原理により, $H_{0}^{L H}$ と $H_{0}^{L}$ がいずれも $\alpha$ で棄却される必要がある が, 既に $H_{0}^{L H}$ は有意水準 $\alpha$ で棄却されているので, 残りの $H_{0}^{L}$ が有意水準 $\alpha$ で棄却されれば良 いことになる，その結果として，各基本仮説を設定した順序に従って有意水準 $\alpha$ で検定し，有意 であれば次の仮説へ進み，有意でなければそれより高い順位の仮説を全て保留するという，よく 知られた検定方式となる.

以上の方法を適応的 2 段階計画に導入する. 試験継続の条件を $\alpha_{1}<p_{1}<\alpha_{0}$ とし, 試験全体の 検定手順及び第 1 種の過誤確率の制御方法に関して, 中間解析後に被験者数再設計のみ行う場合 (6.2 節), 仮説間に順序関係を導入し中間解析後に順序関係あるいは検定の順位を変更する場合 (6.3 節)，及びある用量を中止する場合 (6.4 節)のそれぞれについて解説する．以下，第 1 ステー ジの $H_{0}^{L}, H_{0}^{H}$ ，及び $H_{0}^{L H}$ の検定の $p$ 值を，それぞれ $p_{1}^{L}, p_{1}^{H}$ ，及び $p_{1}^{L H}$ とし，第 2 ステージの それぞれの仮説の検定の $p$ 值を同様に $p_{2}^{L}, p_{2}^{H}, p_{2}^{L H}$ とする.

2 つ以上の基本仮説の積仮説の検定では, $p$ 值の決定に関して注意が必要である. 例えば, $H_{0}^{L H}$ は $\mu_{P}=\mu_{L}=\mu_{H}$ を意味するので, この仮説の検定は 3 群を対象とした分散分析の $F$ 検定から 求めることが出来る. $H_{0}^{L H}$ のもとで, その $p$ 值は $[0,1)$ の一様分布に従う. 他方, $H_{0}^{L}$ と $H_{0}^{H}$ を 個別に Student の $t$ 検定で検定し，それらの $p$ 值を求めて Bonferroni 不等式による多重性調整を 考慮した $p$ 值を用いることも考えられる. 後者の場合, $p_{1}^{L H}=\min \left\{2 \min \left(p_{1}^{L}, p_{1}^{H}\right), 1\right\}$ と定義する と, この調整 $p$ 值は $[0,1)$ の一様分布ではない. したがって, 条件付過誤関数の計算で用いられ ている, 帰無仮説のもとで $p$ 值は一様分布に従うという条件が成り立たない.このような場合で も今までに述べた方法が適用できることを次節で述べる.

\subsection{2 段階検定の $p$ 值の調整}

第 1 ステージの標本のみで計算された $p$ 值を $p_{1}$, 第 2 ステージの標本のみで計算された $p$ 值を $p_{2}$ とする. 第 1 ステージで $p_{1} \leq \alpha_{1}$ のとき帰無仮説を棄却し, $\alpha_{0} \leq p_{1}$ のとき, 帰無仮説を棄て られないとして中止し， $\alpha_{1}<p_{1}<\alpha_{0}$ のとき, 試験を継続し第 2 ステージの標本から $p$ 值を求め 
る. 帰無仮説の下で

$$
\text { 全ての } \alpha \in[0,1] \text { について } \operatorname{Pr} .\left(p_{1} \leq \alpha\right) \leq \alpha, \quad \operatorname{Pr} .\left(p_{2} \leq \alpha \mid p_{1}\right) \leq \alpha
$$

を満たすとする. $p_{1}, p_{2}$ に関するこの性質を Brannath, Posch and Bauer (2002) は「p-clud」と 呼んでいる. 上の条件は， $p_{1}$ の分布及び $p_{1}$ の実現值で条件つけられた $p_{2}$ の分布は $[0,1]$ 上の 一様分布かそれより確率的に大きい分布であることを意味している. この条件の下で, 任意の $\alpha_{1}<p_{1}<\alpha_{0}$ において, 条件付過誤関数が $p_{2}$ の非増加関数であるならば第 1 種の過誤確率は $\alpha$ 以下となる (Hommel (2001)). 即ち, 2 段階検定は第 1 種の過誤確率を制御している. Bonfferoni 不等式を用いて調整した $p$ 值は $\mathrm{p}$-clud の条件を満たしている. 複数の仮説からなる仮説の族に関 する Bonferroni 型検定の改良・拡張検定基準に基づく $p$ 值の定義を Posch et al. (2005) が与えて いる. Brannath, Posch and Bauer (2002) はさらに 2 ステージで統合された $p$ 值を定義する方法 とそれに基づく信頼区間を与えている.

\section{3 例数再設計のみ行う場合}

仮説構造を変更せず例数再設計のみ行う場合, 各ステージで検定対象とする仮説全体とそれら の間の順序関係は全く変わらないため, ステージ毎に同一の仮説構造による閉検定手順を行えば 良い。ただし，第 2 ステージの棄却限界值の設定には注意を払う必要がある. 本 6.3 節と次の 6.4 節では特定用量が第 1 ステージ後の検定で有意となった場合には, その用量を第 2 ステージでは 試験せず，第 2 ステージで試験する用量の被験者数の再計算を考慮しうる場合を扱う。この場合 には, 第 2 ステージでは, 第 1 ステージで棄却されなかった仮説が検定の対象になる. ある用量 を有効中止以外の理由によって中止することを含む場合は 6.5 節にて解説する.

\subsection{1 仮説間に順序関係がない場合}

仮説間に順序関係がない場合は以下のとおりである.

第 1 ステージの検定手順は通常の試験と同様であり, 各仮説の棄却限界值が $\alpha_{1}$ に変わるのみ である. まず積仮説 $H_{0}^{L H}=H_{0}^{L} \cap H_{0}^{H}$ の検定を有意水準 $\alpha_{1}$ で行う.これが有意であった場合 $\left(p_{1}^{L H}<\alpha_{1}\right)$ に各基本仮説 $H_{0}^{L}, H_{0}^{H}$ の検定をそれぞれ $\alpha_{1}$ で行う. その結果, $p_{1}^{L}<\alpha_{1}$ であれば $H_{0}^{L}$ を棄却して低用量の試験を中止する. 同様に $p_{1}^{H}<\alpha_{1}$ であれば $H_{0}^{H}$ を棄却して高用量の試験 を中止する. $p_{1}^{L H}>\alpha_{1}$ であった場合, $\alpha_{1}<p_{1}^{L H}<\alpha_{0}$ であれば第 2 ステージへ継続し, $p_{1}^{L H}>\alpha_{0}$ であれば帰無仮説 $H_{0}^{L H}$ を採択して試験を中止する(図 2 ).

第 2 ステージへ継続した場合, 第 1 ステージと同じ手順に従って検定を進めれば良いが, 第 2 ステージの検定は第 1 ステージの結果 $p_{1}$ または $z_{1}$ を条件とした条件付き検定となるため, 棄 却限界值は条件付き過誤関数 $A\left(p_{1}\right)$ または $A\left(z_{1}\right)$ を用いて仮説ごとに算出する必要がある. 第 2 ステージの棄却限界值は, 積仮説 $H_{0}^{L} \cap H_{0}^{H}$ については $A\left(p_{1}^{L H}\right)$ であり $\left(p_{1}^{L H}\right.$ は検定の多重性 の調整を行った $p$ 值 (調整 $p$ 值)), 基本仮説については $H_{0}^{L}$ には $A\left(p_{1}^{L}\right), H_{0}^{H}$ には $A\left(p_{1}^{H}\right)$ がそれ ぞれ対応する. 結果として, $p_{2}^{L H}<A\left(p_{1}^{L H}\right)$ 且つ $p_{2}^{L}<A\left(p_{1}^{L}\right)$ であれば $H_{0}^{L}$ が棄却され, 同様に $p_{2}^{L H}<A\left(p_{1}^{L H}\right)$ 且つ $p_{2}^{H}<A\left(p_{1}^{H}\right)$ であれば $H_{0}^{H}$ が棄却される(図 3 ).

また, 第 1 ステージにおいて, どちらかの用量の帰無仮説が棄却され, 残りの用量が帰無仮説 を保留する結果となつた場合は $\left(p_{1}^{L H}<\alpha_{1}\right.$ 且つ $p_{1}^{L}<\alpha_{1}$ 且つ $\alpha_{1}<p_{1}^{H}<\alpha_{0}$, 又は, $p_{1}^{L H}<\alpha_{1}$ 且 


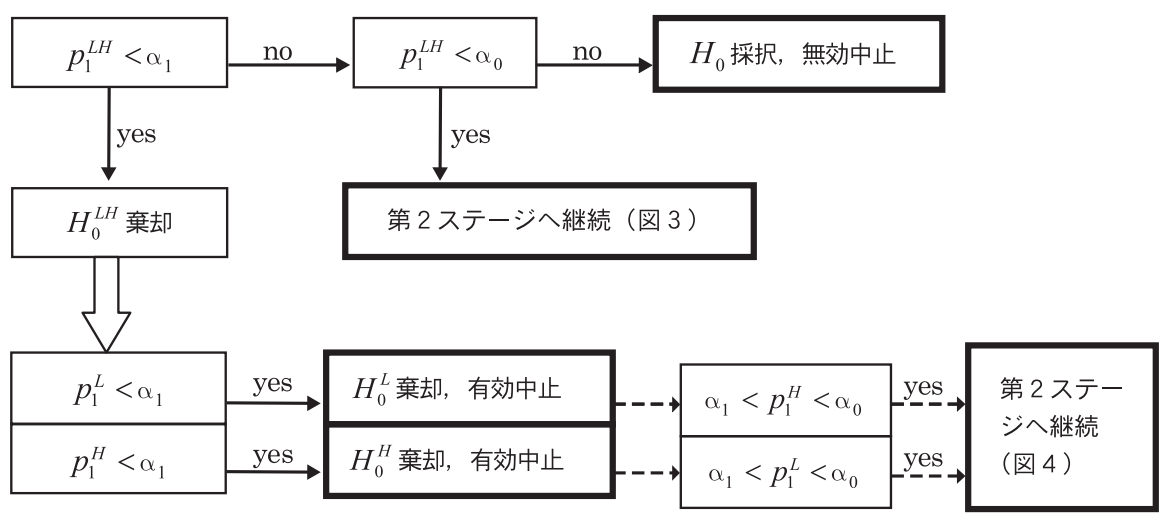

図 2. 仮説間に順序関係がない場合の適応的 2 段階計画における第 1 ステージの検定手順. 点線 の矢印は, 一方の用量のみが有意となり, 残りの用量について試験を継続する場合を示す.

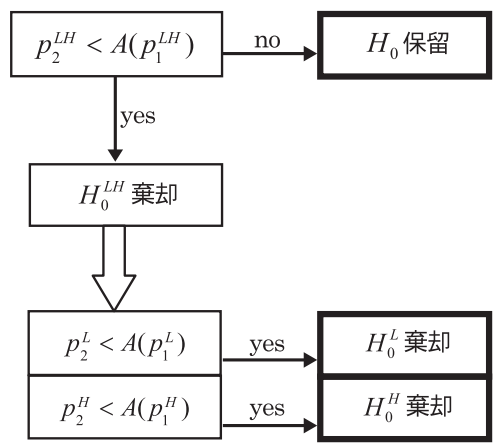

図 3. 仮説間に順序関係がない場合の適応的 2 段階計画における 第 2 ステージの検定手順. 第 1 ステージでいずれの用量も継続と された場合

$つ p_{1}^{H}<\alpha_{1}$ 且つ $\left.\alpha_{1}<p_{1}^{L}<\alpha_{0}\right)$, 有意とならなかつた用量とプラセボだけで試験を継続すること も可能である (図 2 の点線矢印). この場合, 積仮説 $H_{0}^{L H}$ については第 1 ステージで既に棄却さ れているため, 第 2 ステージにおいては継続された用量の基本仮説の検定のみとなる (図 4 ).

\begin{tabular}{|c|c|c|}
\hline$p_{2}^{L}<A\left(p_{1}^{L}\right)$ & yes & $H_{0}^{L}$ 棄却 \\
\hline$p_{2}^{H}<A\left(p_{1}^{H}\right)$ & yes & $H_{0}^{H}$ 棄却 \\
\hline
\end{tabular}

図 4. 仮説間に順序関係がない場合の適応的 2 段階計画における 第 2 ステージの検定手順. ある 1 用量のみが第 2 ステージで試験 された場合

\subsection{2 仮説間に順序関係がある場合}

用量間に重要性に従って順序を導入した場合 $\left(H_{0}^{H} \succ H_{0}^{L}\right)$ の検定手順は以下のとおりである.

第 1 ステージの検定手順は通常の試験と同様であり, 各仮説の棄却限界值が $\alpha_{1}$ に変わるのみ である. 順序に従い，まず仮説 $H_{0}^{H}$ の検定を有意水準 $\alpha_{1}$ で行う. その結果， $p_{1}^{H}<\alpha_{1}$ であれば Jpn J Biomet Vol. 29, Special Issue 1, 2008 


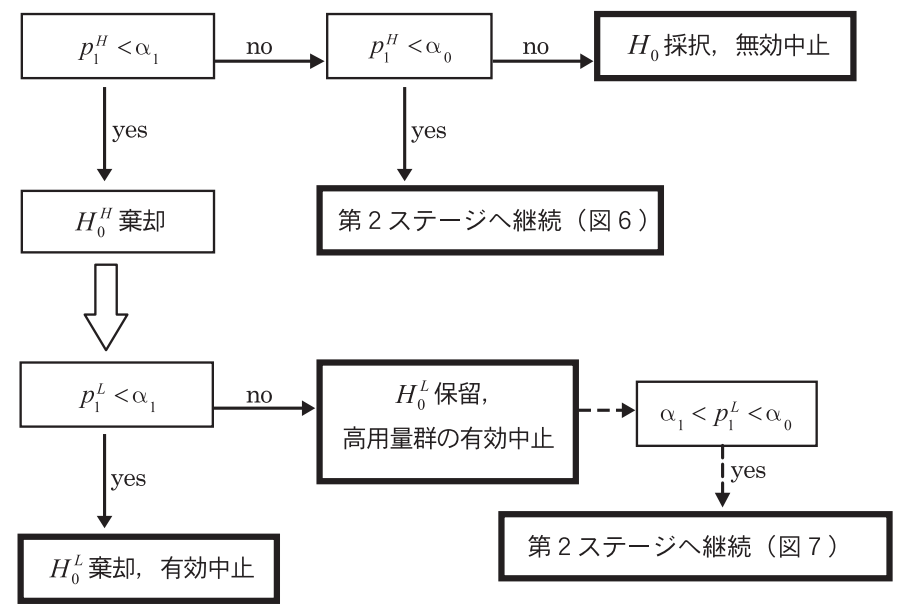

図 5. 仮説に順序 $H_{0}^{H} \succ H_{0}^{L}$ を導入した場合の適応的 2 段階計画における第 1 ステージの検定手 順. 点線の矢印は, 用量 $\mathrm{H}$ のみが有意となり, 用量 L について試験を継続する場合を示す.

$H_{0}^{H}$ を棄却する. $\alpha_{1}<p_{1}^{H}<\alpha_{0}$ であれば第 2 ステージへ継続し, $p_{1}^{H}>\alpha_{0}$ であれば帰無仮説を採 択して試験を中止する. そして, $p_{1}^{H}<\alpha_{1}$ であった場合に限り仮説 $H_{0}^{L}$ の検定を有意水準 $\alpha_{1}$ で 行う. $p_{1}^{L}<\alpha_{1}$ であれば $H_{0}^{L}$ を棄却して試験を中止する. $\alpha_{1}<p_{1}^{L}<\alpha_{0}$ であれば $H_{0}^{L}$ を保留し, 第 2 ステージへの継続と試験中止の判断を行う. $p_{1}^{L}>\alpha_{0}$ であれば $H_{0}^{L}$ を採択して試験を中止す る(図 5).

それぞれの仮説の第 2 ステージでの棄却限界值は, $H_{0}^{H}$ については $A\left(p_{1}^{H}\right), H_{0}^{L}$ については $A\left(p_{1}^{L}\right)$ となることに注意する. まず $H_{0}^{H}$ の検定を行い, $p_{2}^{H}>A\left(p_{1}^{H}\right)$ であれば全ての帰無仮説を 保留して検定を中止する. $p_{2}^{H}<A\left(p_{1}^{H}\right)$ であれば $H_{0}^{H}$ を棄却して $H_{0}^{L}$ の検定に進み, $p_{2}^{L}<A\left(p_{1}^{L}\right)$ であれば $H_{0}^{L}$ を棄却する(図 6 ).

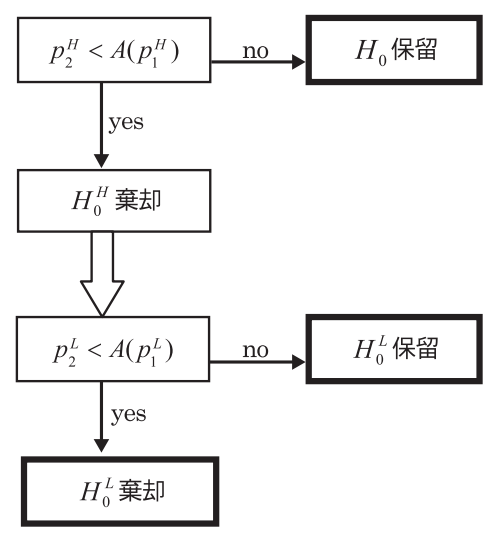

図 6. 仮説に順序 $H_{0}^{H} \succ H_{0}^{L}$ を導入した場合の適応的 2 段階計 画における第 2 ステージの検定手順. 第 1 ステージで用量 $\mathrm{H}$ を 有効中止と判定できず第 2 ステージでも試験する場合 


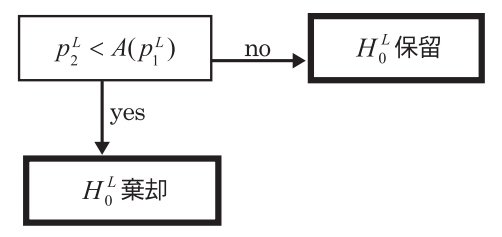

図 7. 適応的 2 段階計画において第 1 ステージの用量 $\mathrm{H}$ の検定 が有意となり第 2 ステージでは低用量 L のみを試験する場合の第 2 ステージの検定手順

第 1 ステージにおいて用量 $\mathrm{H}$ が有意, 用量 $\mathrm{L}$ が保留となつた場合 $\left(p_{1}^{H}<\alpha_{1}\right.$ 且つ $\left.\alpha_{1}<p_{1}^{L}<\alpha_{0}\right)$, 用量 L について試験を継続することが可能である. この場合, 積仮説 $H_{0}^{L} \cap H_{0}^{H}$ については第 1 ステージで既に棄却されているため, 第 2 ステージにおいては継続された用量 $\mathrm{L}$ の基本仮説の検 定のみとなる(図 7).

\section{4 仮説間に順序関係を導入し中間解析後に順序を変更した場合}

Hommel (2001) は，第 1 ステージではいずれの仮説も棄却されず第 2 ステージに進んだとき, 中間解析後に第 2 ステージの仮説の順序を(6.3.2 項の例では $H_{0}^{H} \succ H_{0}^{L}$ から $H_{0}^{L} \succ H_{0}^{H}$ へ) 変更 した場合でも，次節 (6.5 節)で述べる Bauer and Kieser の基本命題を適用することにより，検定 の妥当性を確保できることを述べている．ただし，その際には閉検定手順を正しく適用すること に注意を払う必要がある. 第 2 ステージにおいて, 低用量 $\mathrm{L}$ に関する評価が最も重要として順序 関係を変更した場合, $H_{0}^{L}$ を棄却するためには, 閉検定手順から $H_{0}^{L} \cap H_{0}^{H}$ と $H_{0}^{L}$ の両者が棄却 される必要がある. まず $H_{0}^{L} \cap H_{0}^{H}$ について考えると, 第 2 ステージは $H_{0}^{L} \succ H_{0}^{H}$ と順序が定め られたため $H_{0}^{L} \cap H_{0}^{H}$ を棄却する条件は $H_{0}^{L}$ を棄却することと一致するので, この検定の $p$ 值は $p_{2}^{L H}=p_{2}^{L}$ となる. しかし，第 1 ステージでは $H_{0}^{L} \cap H_{0}^{H}$ の棄却の条件は $H_{0}^{H}$ を棄却することで あったため, $H_{0}^{L} \cap H_{0}^{H}$ の棄却限界値は $A\left(p_{1}^{L H}\right)=A\left(p_{1}^{H}\right)$ となる. つまり, 積仮説 $H_{0}^{L} \cap H_{0}^{H}$ は $p_{2}^{L}<A\left(p_{1}^{H}\right)$ であった場合に棄却される. 基本仮説 $H_{0}^{L}$ は $p_{2}^{L}<A\left(p_{1}^{L}\right)$ であれば棄却される. した がつて, 中間解析後に $H_{0}^{H} \succ H_{0}^{L}$ から $H_{0}^{L} \succ H_{0}^{H}$ へ仮説の順序を変更した場合, $H_{0}^{L}$ を棄却するた めには $p_{2}^{L}<\min \left(A\left(p_{1}^{L}\right), A\left(p_{1}^{H}\right)\right)$ を満たす必要がある. なお, $H_{0}^{L}$ が棄却された後に行われる $H_{0}^{H}$ の検定においては, 積仮説 $H_{0}^{L} \cap H_{0}^{H}$ が棄却済みであるため, 単に $p_{2}^{H}<A\left(p_{1}^{H}\right)$ であれば $H_{0}^{H}$ は 棄却される.

このようにして, 仮説の重要性の順位を第 1 ステージと第 2 ステージで変更したとしても, FWER を制御しつつ検定を実施することは，検定論上は可能である. しかし，検証試験において 中間解析後に事前に定めた順序を変更することは, 試験計画時点での検証仮説の構造が試験結果 に基づいて変更されたことを意味する，そのため，検証試験におけるこのような変更の正当性が 示されることが必要である，通常は，たとえ変更後の主要な仮説が示されたとしても，検証的結 果としてではなく，探索的な結果とみなすのが妥当であろう．なお，検証及び検証試験における 仮説の検証の意味と条件については，本記録集の「検証とは何か」も参照されたい. 


\section{5 中間解析の結果を用いてある用量を中止する場合}

6.3 及び 6.4 節で扱った状況では, 例えば, 第 1 ステージで高用量だけが有効と判定された場 合, 第 1 ステージで有効と判定されなかった他の治療, 即ち低用量の基本仮説と, 有効と判定さ れた治療即ち高用量の基本仮説の双方を含意する帰無仮説は全て棄却されている. したがって, 第 2 ステージでは, 第 1 ステージで対象とした全仮説の中の, 高用量に関する基本仮説を含意し ない仮説のみが，未だ棄却されていない可能性があり，第 2 ステージの検定の対象となる.この ように，第 1 ステージと第 2 ステージの統合検定では，当初設定した全ての仮説が検定の対象と なっており，仮説構造は第 1 ステージと第 2 ステージで同一である.

本節では, 第 1 ステージで統計的検定によつて有効と判定された治療以外の治療について, 中 間解析の結果を基にして中止する場合も含む状況を扱う。この状況では, 第 2 ステージで検定の 対象となる仮説全体は第 1 ステージと異なる. 例えば, 第 1 ステージでいずれの用量も有効と判 定されなかつたが, 第 2 ステージでは高用量は試験されないとしよう.この場合, いずれの用量 に関する基本仮説を取り上げても，それを含意する全ての帰無仮説の中には第 1 ステージで棄却 されなかった仮説がある. 例えば, 高用量と低用量のそれぞれの基本仮説の積仮説 $H_{0}^{L H}$ は第 1 ステージで有意でなかったとする. 第 2 ステージの検定で低用量を有効と判定するためには, 低 用量の基本仮説を含意する仮説の中で, 第 1 ステージで有意 ( $p$ 值が $\alpha_{1}$ 以下) とならなかった仮説 の全てが統合検定で有意になることが必要である.このことは高用量に関する基本仮説を含む仮 説も検定の対象とすることを意味する. 即ち $H_{0}^{L H}$ も検定の対象となる. しかし，第 2 ステージ では高用量群のデー夕は無いため, どのようにして第 2 ステージで $H_{0}^{L H}$ を検定するかが問題で ある.

このための基礎となる理論は Bauer and Kieser の基本命題に示されている. それは以下の通り である.

Bauer and Kieser の基本命題

第 1 ステージで試験される治療群により構成される基本仮説の添え字集合を $\mathbf{K}_{1}=\left\{1, \cdots, K_{1}\right\}$ とする. これは, 基本仮説の集まり $\left\{\widetilde{H}_{01}, \cdots, \widetilde{H}_{0 K_{1}}\right\}$ に対応する. 第 2 ステージで試験される治 療に対応する基本仮説の添え字集合を $\mathbf{K}_{2}$ とする.ここに $\mathbf{K}_{2}$ は空でない $\mathbf{K}_{1}$ の真部分集合であ る. $\mathbf{J} \subseteq \mathbf{K}_{1}$ は，任意の添え字集合とする．この添え字集合に対応する帰無仮説を $H_{0 \mathrm{~J}} ： \bigcap_{j \in \mathbf{J}_{1}} \widetilde{H}_{0 j}$ と表す.

(1) 第 1 ステージでの $H_{0 \mathbf{K}_{1}}: \bigcap_{j \in \mathbf{K}_{1}} \widetilde{H}_{0 j}$ の棄却

$p_{1}^{\mathbf{K}_{1}}<\alpha_{1}$ ならば $H_{0 \mathbf{K}_{1}}$ が棄却される.

第 1 ステージでの基本帰無仮説 $\widetilde{H}_{0 j}$ の検定

添え字 $j$ を含む添え字集合 $\mathbf{J} \subseteq \mathbf{K}_{1}$, 即ち $j \in \mathbf{J} \subseteq \mathbf{K}_{1}$, について, $H_{0 \mathbf{J}}$ の検定の $p$ 值 $p_{1}^{\mathbf{J}}$ を求 める. $j$ を含む $\mathbf{K}_{1}$ の全ての添え字集合の各々に対応する仮説の検定の $p$ 值が $\alpha_{1}$ 以下, 即ち $j \in \mathbf{J} \subseteq \mathbf{K}_{1}$ である全ての $\mathbf{J}$ で $p_{1}^{\mathbf{J}} \leq \alpha_{1}$ となる，ならば $\widetilde{H}_{0 j}$ を棄却する.

(2) 第 2 ステージへの継続

$\alpha_{1}<p_{1}^{\mathbf{K}_{1}} \leq \alpha_{0}$ ならば第 2 ステージへ継続する. 
第 2 ステージでは添え字集合 $\mathbf{K}_{2}$ に含まれる全ての添え字に対応する治療と対照が試験される とする. $\mathbf{K}_{2}$ に含まれる $j$ について, 第 2 ステージでは次の条件が満たされた場合に基本帰無仮 説 $\widetilde{H}_{0 j}$ を棄却する.

「添え字 $j$ を含む添え字集合 $\mathbf{J} \subseteq \mathbf{K}_{1}$ について, $\mathbf{J}_{2}=\mathbf{J} \cap \mathbf{K}_{2}$ とおく. $H_{0 \mathbf{J}_{2}}$ の検定の $p$ 值を $p_{2}^{\mathbf{J}_{2}}$ とする. $j \in \mathbf{K}_{2}$ について， $j$ を含む全ての $\mathbf{J} \subseteq \mathbf{K}_{1}$ のそれぞれに対応する $\mathbf{J}_{2}$ について,

$$
p_{1}^{\mathbf{J}}<\alpha_{1} \text { または, } \quad \alpha_{1}<p_{1}^{\mathbf{J}}<\alpha_{0} \text { かつ } p_{1}^{\mathbf{J}} p_{2}^{\mathbf{J}_{2}} \leq c_{\alpha}
$$

である.」

なお， $j \in \mathbf{J}_{2}$ なので， $\mathbf{J}_{2}$ は空集合ではないことに注意しよう.

先にあげた例に戻って考えよう．第 2 ステージで本来ならば評価されなければならない仮説の 中には低用量と高用量のそれぞれの基本仮説の積 $H_{0}^{L H}$ が含まれている. 第 1 ステージでは, こ の仮説の検定は Bonferroni 基準で検定したとする．第 2 ステージでは高用量の試験をしていない ため，第 1 ステージと同じ検定方法を用いてこの積仮説の検定をすることはできない．即ち，第 2 ステージで検定可能でかつ検定すべき仮説は，有効と判定されなかった全ての用量を含む試験に おいて第 2 ステージで検定すべき仮説全体の一部に過ぎない.このような場合であっても，第 2 ステージで試験された治療の有効, 無効を統合検定によって判定することが出来る. この方法の 基礎となる考えは次のように説明できる.「第 2 ステージで除かれている本来検定対象となるべき 仮説, 例えば $H_{0}^{L H}$ について, 高用量に関する帰無仮説は採択したものとみなす。一方 $H_{0}^{L H}$ は, その要素仮説である低用量の基本仮説が真でなければ真ではない.したがって第 2 ステージの開 始に先立ち, 第 2 ステージのみのデータによる $H_{0}^{L H}$ の検定の $p$ 值を求める検定方法として, 低 用量に関する基本仮説を棄却することによって $H_{0}^{L H}$ を棄却するという検定基準を採用する.」こ のようにして，積仮説に関する統合検定が，第 1 ステージの標本による検定の $p$ 值と第 2 ステー ジのみの標本による検定の $p$ 值の統合による基準に基づいて定義される.

いくつかの注意

Bauer and Kieser は第 2 ステージに進む条件を， $\alpha_{1}<p_{1}^{\mathbf{K}_{1}} \leq \alpha_{0}$ としている. しかし，第 2 ステージで棄却されるためには $p_{1}^{\mathbf{K}_{1}} \leq \alpha_{0}$ でなければならないので, $j$ を含む少なくとも 1 つの $\mathbf{J} \subseteq \mathbf{K}_{1}$ において $\alpha_{0}<p_{1}^{\mathbf{J}}$ であれば, 第 2 ステージにおいても $\widetilde{H}_{0 j}$ は棄却されない. したがって, 第 2 ステージに進める意義のあるのは，その処理を含む全ての添え字集合において，対応する積 仮説の $p$ 值が $\alpha_{0}$ 以下となる場合のみである.

上の方式が語ることは，第 2 ステージへ進む意義のある処理の全てを第 2 ステージに進めなく とも良いということである．この場合，意図的な選択が $p$ 值を見た結果であるとき，上記の第 2 ステージでの検定は第 2 ステージへ進めた処理のみで検定すればよいことになる. したがって, 第 2 ステージに進めることが可能な全ての処理の中から，検定結果に基づいて意図的に 1 つ上 選択して第 2 ステージを実施したとする．この意図的な選択が第 1 種の過誤を増大することにな らないかといつた疑問が残るであろう.この点に関してはさらに考察が必要であろう. 


\subsection{1 仮説間に順序関係がない場合}

仮説間に順序関係がない場合, どちらの用量を中止しても検定手順は同様であるため, 以下は 例として用量 L を中止した場合について記す.ここでの中止は, 第 1 ステージの検定によって低 用量の効果に関する基本仮説を棄却して第 2 ステージでの試験を中止するのでなく, 基本仮説を 棄却できなかったけれども中止した場合である. 第 1 ステージの検定手順は図 2 に記したとおり である.

第 2 ステージにおいて $H_{0}^{H}$ を棄却するためには, 第 1 ステージと同様, $H_{0}^{L H}$ と $H_{0}^{H}$ の両者が 棄却される必要があるため, 棄却限界值はそれぞれ $A\left(p_{1}^{L H}\right)$ と $A\left(p_{1}^{H}\right)$ となる. ただ, 第 2 ステー ジではデータがプラセボ群と用量 $\mathrm{H}$ 群に限られるため, 第 2 ステージにおける $H_{0}^{L H}$ の検定は, $H_{0}^{H}$ と $H_{0}^{L}$ の少なくとも一方を棄却するのでなく, $H_{0}^{H}$ を棄却することによって $H_{0}^{L H}$ を棄却す るという検定方式に変更する. これより, 第 2 ステージでの $H_{0}^{L H}$ の検定の $p$ 值は $p_{2}^{L H}=p_{2}^{H}$ と なる. したがって, 統合検定方式では $p_{2}^{H}<A\left(p_{1}^{L H}\right)$ のとき, $H_{0}^{L H}$ を棄却する. また, $H_{0}^{H}$ の有 意水準 $\alpha$ の統合検定は, 第 2 ステージにおいて $p_{2}^{H}<A\left(p_{1}^{H}\right)$ の場合に有意である. したがって, 閉手順の原理によって $p_{2}^{H}<\min \left(A\left(p_{1}^{L H}\right), A\left(p_{1}^{H}\right)\right)$ であれば $H_{0}^{H}$ が棄却される.

\subsection{2 仮説間に順序関係がある場合}

事前に, 仮説に順序関係 $H_{0}^{H} \succ H_{0}^{L}$ を導入した場合, ぞちらの用量を中止するかにより第 2 ステージの検定手順が異なる.ここでは, 例えば, 用量反応の単調性を前提とした仮説では, $H_{0}^{H} \cap H_{0}^{L}=H_{0}^{H}$ であり, 単調性を仮定しない場合には $H_{0}^{L H}$ は $H_{0}^{H}$ を棄却することによって棄 却するという検定方式を採用する. これによって, 第 1 ステージの用量 $\mathrm{H}$ の検定で $H_{0}^{H}$ が保留 $\left(\alpha_{1}<p_{1}^{H}<\alpha_{0}\right)$ となり, 第 2 ステージにおいて用量 $\mathrm{L}$ は試験されなかった場合, $H_{0}^{H}$ の検定手順 は図 6 の上半分である用量 $\mathrm{H}$ の検定までの手順と同様である.

第 1 ステージの用量 $\mathrm{H}$ の検定で $H_{0}^{H}$ が棄却 $\left(p_{1}^{H}<\alpha_{1}\right)$ され, 用量 $\mathrm{L}$ は $H_{0}^{L}$ の検定で棄却され なかったことにより, 第 2 ステージにおいて用量 L のみが試験された場合, 第 2 ステージでの用 量 $\mathrm{L}$ の検定は, $H_{0}^{L H}$ は棄却済みのため図 6 の下半分である用量 $\mathrm{L}$ の検定と同様である.

第 1 ステージの用量 $\mathrm{H}$ の検定で $H_{0}^{H}$ が保留となり, 安全性などの理由から第 2 ステージにお いて用量 $\mathrm{H}$ は試験されなかった場合, 第 2 ステージにおける $H_{0}^{L H}$ の検定は, $H_{0}^{L}$ を棄却できる 場合にのみ $H_{0}^{L H}$ を棄却するという検定方式を採用する. この検定方式は用量反応の単調性を仮 定した仮説構造であっても, 重要性の順位による検定順序の順序関係の場合であっても同様であ る. ただし，用量 L に関する第 1 ステージでの仮説の検定の $p$ 值 $\left(p_{1}^{L}\right)$ は, 第 1 ステージで予定し ていた検定方式によって求めなければならない(図 8).

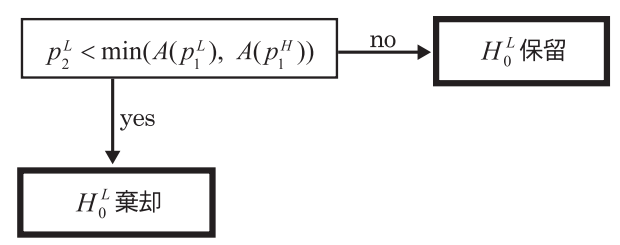

図 8. 適応的 2 段階計画における, 第 1 ステージの用量 $\mathrm{H}$ の検 定が保留となり, 仮説の順序は $H_{0}^{H} \succ H_{0}^{L}$ のまま変更しないが用 量 $\mathrm{H}$ を中止した場合の第 2 ステージの検定手順 


\section{7. 事 例 紹 介}

適応的計画を使った事例として，A-HeFT 試験 (Taylor et al. (2004)) とZeymer et al. による報 告 (2001) を紹介する. A-HeFT 試験は被験者数再設定を行った試験である. 黒人の心不全患者を 対象としたプラセボ対照の 2 群比較試験で, 2 回の中間解析の結果に基づく試験中止と被験者数 再設計を計画した. 400 例／群にて開始した後， 1 回目の中間解析後に 550 例／群と再設計し，2 回目の中間解析にて有意差が認められたことにより試験を中止した. その後, 試験薬は黒人にお ける心不全治療薬として FDA により承認された. Zeymer et al. による報告は複数用量の絞り込 みを行った試験である．急性心筋梗塞を疑わせる患者を対象としたプラセ対照， 4 用量 $(50,100$, $150,200 \mathrm{mg}$ )の比較試験で，1回の中間解析の結果に基づく試験中止，被験者数再設計，用量選択 を計画した. 100 例／群で開始した後, 中間解析後に 100, $150 \mathrm{mg}$ 群を選択して例数を 316 例／ 群に再設計したものの，最終解析にてプラセボとの間に有意差は認められなかった.

\section{8. おわりに}

適応的計画における試験全体の第 1 種の過誤確率は本稿の方法により制御可能であり，この理 論はほぼ成熟していると思われる．ただ，それ以外の例えば推定や実施(本計画に合わせたプロト コールの整備, 独立データモニタリング委員会の設立, 関係者の教育, SOP の作成, 薬剤供給方 法の確立など) における課題は未解決なものが多い. 特に本邦では中間解析の経験自体が少なく, 適応的計画による試験を実施する基盤が整っていないのが現状であろう。しかし，実施に至らず とも試験立案時に適応的計画を検討する機会が増加すると考えられ，検討するためには第 1 種の 過誤確率は制御可能であることを，社内外の関係する人々に説明できることが前提の一つと思わ れる. そのため, 特に試験の立案と実施に直接関わる統計担当者の方々が, 本稿を足がかりとし て適応的計画の理解を深めていただくことを期待している.

\section{謝辞}

原稿を丁寧に読み, 多数の説明不足な箇所ならびに不備をご指摘いただいた森川敏彦久留米大 学教授ならびに查読者の方々に心よりお礼申し上げます.

\section{参 考 文 献}

Bauer, P. and Kieser, M. (1999). Combining different phases in the development of medical treatments within a single trial. Statistics in Medicine 18, 1833-1848.

Bauer, P. and Kohne, K. (1994). Evaluation of experiments with adaptive interim analysis. Biometrics 50, 1029-11041.

Brannath, W., Posch, M. and Bauer, P. (2002). Recursive combination tests. Journal of the American Statistical Association 97, 236-244.

Bretz, F., Schmidli, H., Konig, F., Racine, A. and Maurer, W. (2006). Confirmatory seamless phase II/III clinical trials with hypotheses selection at interim: general concepts. Biometrical Journal 48, 623-634.

Jpn J Biomet Vol. 29, Special Issue 1, 2008 
Fisher, R. A. 1925, $13^{\text {th }}$ edition, 1958; Statistical Methods for Research Workers. Oliver \& Boyd Ltd. 研究者のための統計的方法. 遠藤健児, 鍋谷清治 訳. 森北出版; section21.1.

Hommel, G. (2001). Adaptive modifications of hypotheses after an interim analysis. Biometrical Journal 43, 581-589.

Posch, M., Koenig, F., Branson, M. Brannath, W., Dunger-Baldauf, C. and Bauer, P. (2005). Testing and estimation in flexible group sequential designs with adaptive treatment selection. Statistics in Medicine 24, 3697-3714.

Proschan, MA. and Hunsberger, SA. (1995). Designed extension of studies based on conditional power. Biometrics 51, 1315-1324.

Taylor, AL., Ziesche, S., Yancy, C., Carson, P., D'Agostino, R Jr., Ferdinand, K., Taylor, M., Adams, K., Sabolinski, M., Worcel, M. and Cohn, JN.; African-American Heart Failure Trial Investigators. (2004). Combination of isosorbide dinitrate and hydralazine in blacks with heart failure. New England Journal of Medicine 351, 2049-2057.

Zeymer, U., Suryapranata, H., Monassier, JP., Opolski, G., Davies, J., Rasmanis, G., Linssen, G., Tebbe, U., Schroder, R., Tiemann, R., Machnig, T. and Neuhaus, KL.; ESCAMI Investigators. (2001). The $\mathrm{Na}(+) / \mathrm{H}(+)$ exchange inhibitor eniporide as an adjunct to early reperfusion therapy for acute myocardial infarction. Results of the evaluation of the safety and cardioprotective effects of eniporide in acute myocardial infarction (ESCAMI) trial. Journal of American College of Cardiology 38, 1644-1651.

丹後俊郎 (2003). 無作為化比較試験. 朝倉書店; 6.6 節.

三輪哲久 (2008). 多重検定の基礎理論 Basic Principles of Multiple Test Procedures 計量生物学, 29 巻特別号 1.

森川敏彦 (2008). 臨床試験における多重性問題への統計的接近法 Statistical Approaches to Multiplicity Issues in Clinical Trials 計量生物学, 29 巻特別号 1. 